\title{
Effect of Reaction Product of Epichlorohydrin and Imidazole on the Electrodeposition Behavior of Zn-Ni Alloy from Alkaline Zincate Solution
}

\author{
Seonghwa $\mathrm{BAE}^{1)}$, Satoshi OuE ${ }^{2)}$, In-Joon $\mathrm{SON}^{3)}$ and Hiroaki $\mathrm{NAKANO}^{2)^{*}}$ \\ 1) Graduate School of Engineering, Kyushu University \\ 2) Faculty of Engineering, Kyushu University \\ 3) Department of Materials Science and Metallurgy, Kyungpook National University
}

Abstract: Electrodeposition of $\mathrm{Zn}-\mathrm{Ni}$ alloy was performed on a $\mathrm{Cu}$ electrode at a current density of $10-5000 \mathrm{~A} \cdot \mathrm{m}^{-2}$ and a charge of $5 \times 10^{4} \mathrm{C} \cdot \mathrm{m}^{-2}$ in an unagitated zincate solution at $293 \mathrm{~K}$ containing the reaction product of epichlorohydrin and imidazole as brightener. The effect of brightener on the deposition behavior of $\mathrm{Zn}-\mathrm{Ni}$ alloy was investigated. The transfer current density at which the deposition behavior shifts from the normal type to anomalous was 50 to $100 \mathrm{~A} \cdot \mathrm{m}^{-2}$ in brightener-free solution, while it became 10 to 20 $\mathrm{A} \cdot \mathrm{m}^{-2}$ with an addition of brightener, indicating that the brightener greatly decreased the transfer current density. The transfer current density corresponded to the current density at which the potential of total polarization curve significantly shifted from the more noble region than the equilibrium potential of $\mathrm{Zn}$ to less noble region. With an addition of brightener, the decrease in transfer current density is attributed to suppression of hydrogen evolution, and the current efficiency for alloy deposition at high current density region decreased due to suppression of both $\mathrm{Zn}$ and Ni deposition. The Ni content of deposited films decreased with brightener, indicating that Ni deposition was more suppressed with brightener. With increasing current density, the crystals of films deposited from the solution containing brightener became smooth and showed the significant brightness. The oxidation reaction of films deposited from the solution containing brightener is suppressed, as a result, the corrosion potential shifted to noble direction.

Keywords: zincate; zinc-nickel alloy; electrodeposition; brightener; anomalous codeposition; polarization curve; current density; transfer current; current efficiency; corrosion potential.

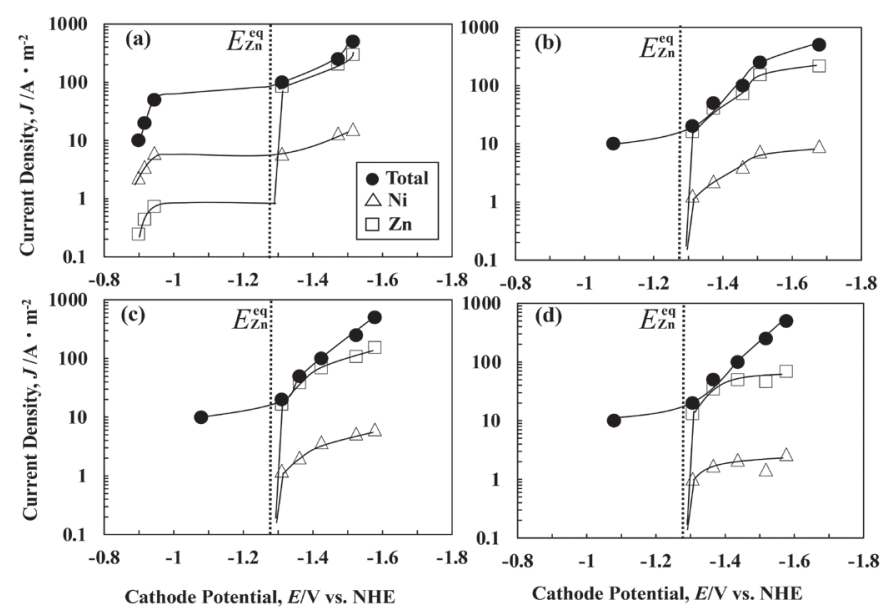




\title{
アルカリジンケート浴からの ZnーNi合金電析挙動に 及ぼすエピクロルヒドリンーイミダゾール反応物の影響
}

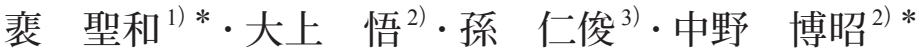

Effect of Reaction Product of Epichlorohydrin and Imidazole on the Electrodeposition Behavior of Zn-Ni alloy from Alkaline Zincate Solution

Seonghwa Bae, Satoshi Oue, In-Joon Son and Hiroaki NaKano

\section{1. 諸言}

電気 $\mathrm{Zn}$ - Ni合金めつきは, 耐食性に優れているため, 自動車部品, 家庭電化製品, 建材用部品などにおいて適用 されている ${ }^{1-3)}$ 。特に, 耐熱防食性能が要求される自動車 エンジン回りの部品に多く使用されている。Zn - Ni 合金 めっきは, 通常, 硫酸塩浴, 塩化物浴から行われるがシア ン化物浴, ジンケート浴等のアルカリ性浴からの方が均一 電着性に優れている ${ }^{4,5)}$ 。しかし，シアンは有毒物質である ので，環境問題の観点からジンケート浴の方が望ましい。 硫酸塩浴, 塩化物浴からの $\mathrm{Zn}-\mathrm{Ni}$ 合金電析は, 電気化学 的に卑な Zn が貴な Niより優先析出する変則型共析挙動を 示すことが知られている ${ }^{6-10)}$ 。

一方，ジンート浴からの Zn- Ni合金の電析挙動は, 電析条件に応じて正常型を示す場合と変則型を示す場合が 報告 ${ }^{11-16)}$ されており, 硫酸塩浴, 塩化物浴からの場合に比 べて不明な点が多い。そこで著者らは, $\mathrm{Ni}^{2+}$ の錯化剂とし てトリエタノールアミン, エチレンジアミンを添加したジ ンケート浴からのZn-Ni合金電析挙動について調査し, ジンケート浴に拈いても低電流密度域では正常型共析と なり, 電流密度が増加すると変則型共析となることを報告 した ${ }^{17-20)}$ 。ジンケート浴からの電析においては, 光沢剂が 添加されており，それらが電析挙動に影響を及ぼしている 可能性もあるが，電析挙動に及ぼす光沢劑の影響について は明らかにされていない。そこで，本研究では，ジンケー 卜浴からの Zn 電析において, 光沢効果のあることが報告 されているエピクロルヒドリンとイミダゾールの反応物 ${ }^{21)}$ を光沢剤として選定し, $\mathrm{Zn}-\mathrm{Ni}$ 合金電析挙動に及ぼす光 沢剂の影響を $\mathrm{Zn}, \mathrm{Ni}$ 析出扎よび水素発生の部分分極曲線 により考察した。

\section{2. 実験方法}

Table 1 にジンケート浴の電解浴組成扎よび電解条 件を示す。電解浴は市販の特級試薬を用い, $\mathrm{ZnO} 0.15$ $\mathrm{mol} \cdot \mathrm{dm}^{-3}, \mathrm{NiSO}_{4} \cdot 6 \mathrm{H}_{2} \mathrm{O} 0.016 \mathrm{~mol} \cdot \mathrm{dm}^{-3}, \mathrm{~N}\left(\mathrm{CH}_{2} \mathrm{CH}_{2} \mathrm{OH}\right)_{3}$ $0.34 \mathrm{~mol} \cdot \mathrm{dm}^{-3}, \mathrm{NaOH} 2.5 \mathrm{~mol} \cdot \mathrm{dm}^{-3}$ を純水に溶解させて作 製した。一部，合金成分を含まない浴からの水素発生挙動 を調査したが，その際の浴組成は，上記の浴から $\mathrm{ZnO} 0.15$ $\mathrm{mol} \cdot \mathrm{dm}^{-3}$ と $\mathrm{NiSO}_{4} \cdot 6 \mathrm{H}_{2} \mathrm{O} 0.016 \mathrm{~mol} \cdot \mathrm{dm}^{-3}$ を抜いたもので ある。エピクロルヒドリンとイミダゾールの反応物は, 既 報 ${ }^{21,22)}$ に従い作製した。エピクロルヒドリンとイミダゾー ルの反応物 (以下, 光沢剤と称す) の構造式を Fig.1 に示す。 電析は, 定電流電解法により電流密度 $10 \sim 500 \mathrm{~A} \cdot \mathrm{m}^{-2}$, 通 電量 $5 \times 10^{4} \mathrm{C} \cdot \mathrm{m}^{-2}$, 浴温 $293 \mathrm{~K}$ において無擋拌下で行なっ た。陰極には $\mathrm{Cu}$ 板 $(1 \mathrm{~cm} \times 2 \mathrm{~cm})$, 陽極にはPt板 $(1 \mathrm{~cm} \times$ $2 \mathrm{~cm}$ )を用いた。得られた電析物は硝酸で溶解し, ICP 発光 分光分析法により Zn, Ni を定量し, 電析合金組成, Zn, Ni 電析の電流効率を求めた。 $\mathrm{Zn}, \mathrm{Ni}, \mathrm{H}_{2}$ の部分電流密度は, 全 電流密度にそれぞれの電流効率 $(\%) / 100$ を乗じて算出し た。水素発生の電流効率は, 100 から Zn, Niの電流効率 $(\%)$ を差し引いて求めた。分極曲線を測定する際，参照電極と して $\mathrm{Ag} / \mathrm{AgCl}$ 電極（飽和 $\mathrm{KCl}, 0.199 \mathrm{~V}$ vs. NHE, $298 \mathrm{~K}$ ) を使 用したが，電位は標準水素電極基準に換算して表示した。

Table 1. Solution compositions and electrolysis conditions.

\begin{tabular}{lr|lr}
\hline $\mathrm{ZnO}\left(\mathrm{mol} \cdot \mathrm{dm}^{-3}\right)$ & 0.15 & Current density $\left(\mathrm{A} \cdot \mathrm{m}^{-2}\right)$ & $10 \sim 500$ \\
$\mathrm{NiSO}_{4} \cdot 6 \mathrm{H}_{2} \mathrm{O}\left(\mathrm{mol} \cdot \mathrm{dm}^{-3}\right)$ & 0.016 & Temperature $(\mathrm{K})$ & 293 \\
$\mathrm{~N}\left(\mathrm{CH}_{2} \mathrm{CH}_{2} \mathrm{OH}\right)_{3}\left(\mathrm{~mol} \cdot \mathrm{dm}^{-3}\right)$ & 0.34 & Amount of charge $\left(\mathrm{C} \cdot \mathrm{m}^{-2}\right)$ & $5 \times 10^{4}$ \\
$\mathrm{NaOH}\left(\mathrm{mol} \cdot \mathrm{dm}^{-3}\right)$ & 2.5 & Cathode & $\mathrm{Cu}\left(1 \times 2 \mathrm{~cm}^{2}\right)$ \\
\multicolumn{2}{l}{ Reaction product of epichlorohydrin } & Anode & $\mathrm{Pt}\left(1 \times 2 \mathrm{~cm}^{2}\right)$ \\
\multicolumn{2}{l}{ and imidazole $\left(\mathrm{ml} \cdot \mathrm{dm}^{-3}\right)$} & $0 \sim 5$ & Quiescent bath \\
\hline
\end{tabular}


電析膜の表面形態は走査型電子顕微鏡 $(\mathrm{SEM})$ により, また構造はX線回折装置 $(\mathrm{Co}-\mathrm{K} \alpha$, 管電圧 $40 \mathrm{kV}$, 管電流 $36 \mathrm{~mA})$ により調べた。電析膜の結晶子のサイズは, X線の $10 \overline{11}$ 反射の半值幅から Scherrerの式 ${ }^{23)}$ を用いて算出した。 電析膜の耐食性を評価するための分極曲線は, 酸素を飽和 させた $313 \mathrm{~K} の 3 \mathrm{mass} \% \mathrm{NaCl}$ 水溶液中に扎て, 電位掃引 法により $1.0 \mathrm{mV} \cdot \mathrm{s}^{-1}$ の速度で卑な電位から貴な電位に移 行させ測定した。

\section{3. 結果および考察}

\section{$3 \cdot 1$ 電析膜の外観に及ぼす光沢剤の影響}

Fig. 2 に光沢剂有り無しの浴において種々の電流密度で 得られた $\mathrm{Zn}$ - Ni 合金電析膜の外観を示す。光沢剤が無い 場合, 何れの電流密度域においても電析膜は灰色で無光沢 であったが, 光沢剤を $2 \mathrm{ml} \cdot \mathrm{dm}^{-3}$ 添加すると $20 \mathrm{~A} \cdot \mathrm{m}^{-2}$ にて 若干光沢が生じ, $50 \mathrm{~A} \cdot \mathrm{m}^{-2}$ 以上では光沢のある銀色となり 電流密度が高くなるほど光沢が顕著となった。

\section{$3 \cdot 2 \mathrm{Zn}-\mathrm{Ni}$ 合金の電析挙動に及ぼす光沢剤の影響}

Fig.3にZn-Ni合金電析における全分極曲線およびZn, $\mathrm{Ni}$ の部分分極曲線を示す。なお, 純Znが析出すると仮定 した場合の $\mathrm{Zn}$ 電析の平衡電位 $\mathrm{E}_{\mathrm{Zn}}{ }^{\mathrm{eq}}$ はー $1.27 \mathrm{~V}$ である。ま た, Niイオンにはトリエタノールアミンが2配位してお り，その錯安定化定数 ${ }^{24)} K=10^{4.74}$ を元に純 $\mathrm{Ni}$ が析出すると

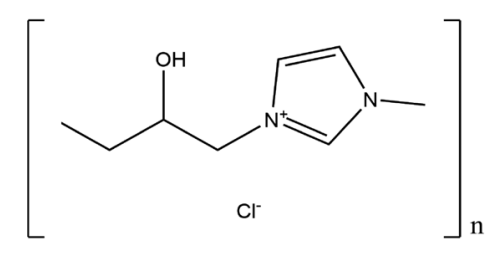

Fig. 1. Structural formula of reaction product of epichlorohydrin and imidazole.
仮定した場合に算出される $\mathrm{Ni}$ 電析の平衡電位 $\mathrm{E}_{\mathrm{Ni}}{ }^{\mathrm{eq}}$ はー 0.41 Vである。光沢剤が無い場合 (Fig.3 (a)), 全分極曲線は, - $0.85 \mathrm{~V}$ 前後で立ち上がり, 電流密度が $50 \mathrm{~A} \cdot \mathrm{m}^{-2}$ を超える と, 電位が急激に卑な方に移行した。電位が約一 $1.3 \mathrm{~V} よ り$ 卑になるとに, 再度電流密度の増加が見られた。一方, Zn の部分分極曲線では, $-0.9 \mathrm{~V}$ 前後より $\mathrm{Zn}$ の部分電流密度 が検出され, その後, 全分極曲線と同様に大きく卑な電位 に移行し, $\mathrm{Zn}$ 電析の平衡電位 $-1.27 \mathrm{~V}$ より卑になると部 分電流密度が急激に増加した。このように, 合金電析にお いても Zn電析が本格的に始まるのは, Znの平衡電位より, 卑な領域になってからであることが分かる。なお, $\mathrm{Zn}-\mathrm{Ni}$ 合金電析では, $\mathrm{Zn}$ 電析の電流密度はその平衡電位より貴な $-0.9 \mathrm{~V}$ 前後においても若干検出されており, 見掛け上 $\mathrm{Zn}$ の underpotential depositionが生じていることが分かった。 次に, $\mathrm{Ni}$ の部分電流密度は, $-0.9 \mathrm{~V}$ 前後で増加し始め, そ の後 $\mathrm{Zn}$ の平衡電位付近まで約 $6 \mathrm{~A} \cdot \mathrm{m}^{-2}$ と一定となり, $\mathrm{Zn}$ の平衡電位より卑になるとやや増加した。

光沢剂を $1 \mathrm{ml} \cdot \mathrm{dm}^{-3}$ となるように添加した浴からの電析 では (Fig.3 (b)), 全分極曲線, Zn, Niの部分分極曲線の何 れも光沢骭が無い場合に比べ大きく分極した。全分極曲線 では, 電流密度が $10 \mathrm{~A} \cdot \mathrm{m}^{-2}$ を超えると, 電位が急激に卑な 方に移行した。この電位が大きく卑な方に移行する電流密 度は, 光沢剤が無い場合より低くなった。一方, $\mathrm{Zn}, \mathrm{Ni}$ の部 分分極曲線は, $\mathrm{Zn}$ の平衡電位より卑な電位域で立ち上が り, $-1.5 \mathrm{~V}$ より卑な電位で部分電流密度が一定に近づい た。ー $1.5 \mathrm{~V}$ より卑な電位域での $\mathrm{Zn}, \mathrm{Ni}$ 析出は, $\mathrm{Zn}^{2+}, \mathrm{Ni}^{2+}$ イ オンの拡散限界に近づいていることを示している。ところ で, 光沢剂が無い場合, $\mathrm{Zn}$ の平衡電位より貴な $-0.9 \mathrm{~V}$ 前後 においても Znが析出しており, 見掛け上Znの underpotential depositionが生じていたが，光沢剤を含む溶液においては， そのような現象は見られなかった。 ZnーNi合金電析にお けるZnの underpotential depositionは, 電析により安定な金

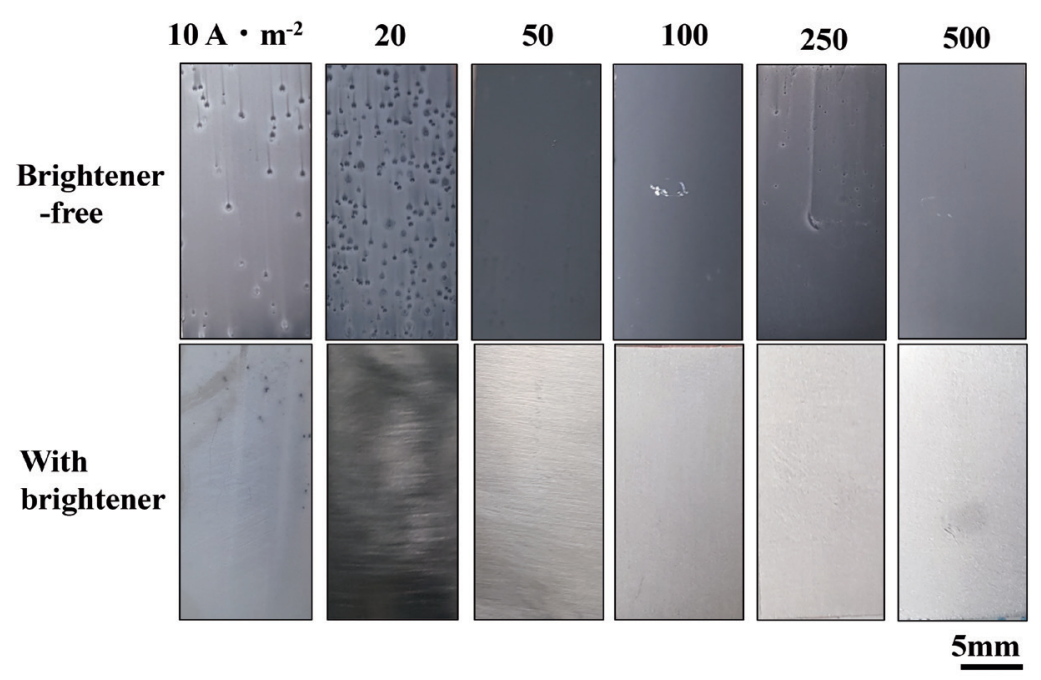

Fig. 2. Appearance of Zn-lvı alıy nıms deposıted at varıous current densıtıes rrom tne solutıons witn and witnout brightener. (Brightener $2 \mathrm{ml} \cdot \mathrm{dm}^{-3}$ ) (online version in color). 
属間化合物 $\mathrm{Ni}_{5} \mathrm{Zn}_{21}$ が形成され, 電析膜の $\mathrm{Zn}$ の活量係数が かなり小さくなるため生じることが報告されている ${ }^{17,19) 。 ~}$ すなわち, Znの underpotential depositionが生じるために はNiの共析が必須となるが，本研究の添加剤を含む浴で は， Niの析出が大きく抑制されており， Znの平衡電位よ り貴な電位域ではNiが析出しないため Znの underpotential depositionが生じなかったと考えられる。

光沢剤を $3 \mathrm{ml} \cdot \mathrm{dm}^{-3}$ となるように添加した浴からの電 析 (Fig.3 (c)) では, 光沢剂 $1 \mathrm{ml} \cdot \mathrm{dm}^{-3}$ (Fig.3 (b)) の場合 とほぼ同様の傾向を示した。詳細に見ると, Zn, Niの部分 電流密度は，光沢剂を $3 \mathrm{ml} \cdot \mathrm{dm}^{-3}$ とすると， $1 \mathrm{ml} \cdot \mathrm{dm}^{-3}$ の 場合より低下することが分かった。光沢骫を $5 \mathrm{ml} \cdot \mathrm{dm}^{-3}$ に 増加すると (Fig.3 (d)), Zn, Niの部分電流密度は光沢剂 3 $\mathrm{ml} \cdot \mathrm{dm}^{-3}$ の場合より更に低下した。特にー $1.4 \mathrm{~V} よ り$ 卑な電 位域では, $\mathrm{Zn}, \mathrm{Ni}$ の析出は, $\mathrm{Zn}^{2+}, \mathrm{Ni}^{2+}$ イオンの拡散限界に 到達しており, 光沢剂により $\mathrm{Zn}^{2+}, \mathrm{Ni}^{2+}$ の拡散が抑制される ことを示唆している。

Fig.4に Zn - Ni 合金電析における析出金属全体の電流効 率に及ぼす電流密度の影響を示す。光沢剤が無い場合, 合 金電析の電流効率は, $10 \sim 50 \mathrm{~A} \cdot \mathrm{m}^{-2}$ の低電流密度域では 15 〜 25\% 程度と低かったが, 電流密度が $50 \mathrm{~A} \cdot \mathrm{m}^{-2}$ を超えると 急激に増加し, 100〜 $200 \mathrm{~A} \cdot \mathrm{m}^{-2}$ で最大となり, 更に電流密 度が増加すると電流効率は低下した。Fig.3 (a) の分極曲線 と対比すると, 10〜 $50 \mathrm{~A} \cdot \mathrm{m}^{-2}$ は, $\mathrm{Zn}$ の平衡電位より貴な電 位となっており，このため電流効率は低いと考えられる。 電流密度が $50 \mathrm{~A} \cdot \mathrm{m}^{-2}$ を超えると電位が $\mathrm{Zn}$ の平衡電位より 卑な電位域に移行しており (Fig.3 (a)), このため電流効率 が急激に増加したと考えられる。電流密度が $500 \mathrm{~A} \cdot \mathrm{m}^{-2}$ に なると電流効率が低下したのは, $\mathrm{Zn}, \mathrm{Ni}$ 析出が, $\mathrm{Zn}^{2+}, \mathrm{Ni}^{2+}$ イオンの拡散限界に近づくためと推察される。一方, 光沢
剂を添加すると, その添加量に関わらず, 電流効率は電流 密度 $10 \mathrm{~A} \cdot \mathrm{m}^{-2}$ ではほぼゼロであったが $10 \mathrm{~A} \cdot \mathrm{m}^{-2}$ を超える と急激に増加し，20〜 $50 \mathrm{~A} \cdot \mathrm{m}^{-2}$ で最大となり, $50 \mathrm{~A} \cdot \mathrm{m}^{-2}$ を 超えると大きく低下した。光沢剂を含む浴では, $10 \mathrm{~A} \cdot \mathrm{m}^{-2}$ を超えると電位が $\mathrm{Zn}$ の平衡電位より卑な領域に移行して おり（Fig.3 (b-d)), このため電流効率が増加し, 20〜 50 $\mathrm{A} \cdot \mathrm{m}^{-2}$ では無添加の場合よりかなり大きくなったと考えら れる。一方, 全電流密度が $100 \mathrm{~A} \cdot \mathrm{m}^{-2}$ を超えると $\mathrm{Zn}, \mathrm{Ni}$ 析 出が $\mathrm{Zn}^{2+}, \mathrm{Ni}^{2+}$ イオンの拡散限界に到達または近づいてお り (Fig.3 (b-d)), 電流密度が高くなるほど電流効率が低下 したと考えられる。100 A $\mathrm{m}^{-2}$ 以上の領域では, 電流効率 は光沢剂を添加した方が低くなっており, 総じて光沢剂の 添加量が多くなる程低下した。光沢剤の添加量が多くなる 程, $\mathrm{Zn}, \mathrm{Ni}$ の析出がより抑制されることを示している。

Fig.5にZn - Ni合金電析膜の Ni含有率に及ぼす電流密 度の影響を示す。眓中の破線は, Niについてその浴組成 と合金組成が等しい場合を示す組成参照線 (Composition

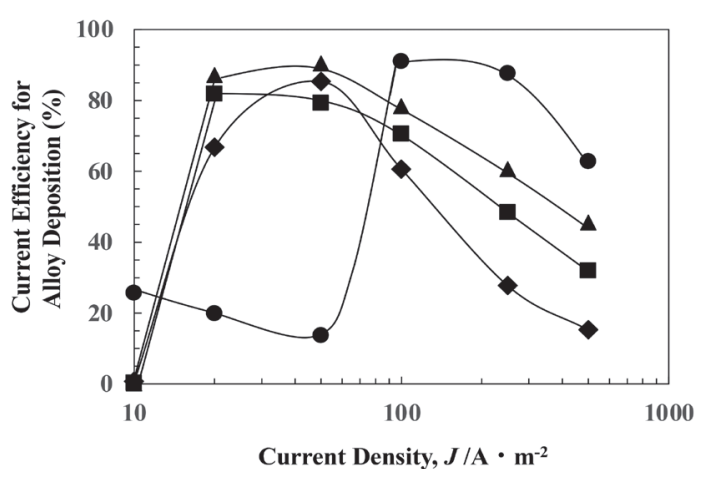

Fig. 4. Current efficiency for Zn-Ni alloy deposition from the solutions with and without brightener. [• Brightenerfree, $\boldsymbol{\Delta}$ Brightener $\left.1 \mathrm{ml} \cdot \mathrm{dm}^{-3}, \mathbf{m} 3 \mathrm{ml} \cdot \mathrm{dm}^{-3}, \cdot 5 \mathrm{ml} \cdot \mathrm{dm}^{-3}\right]$
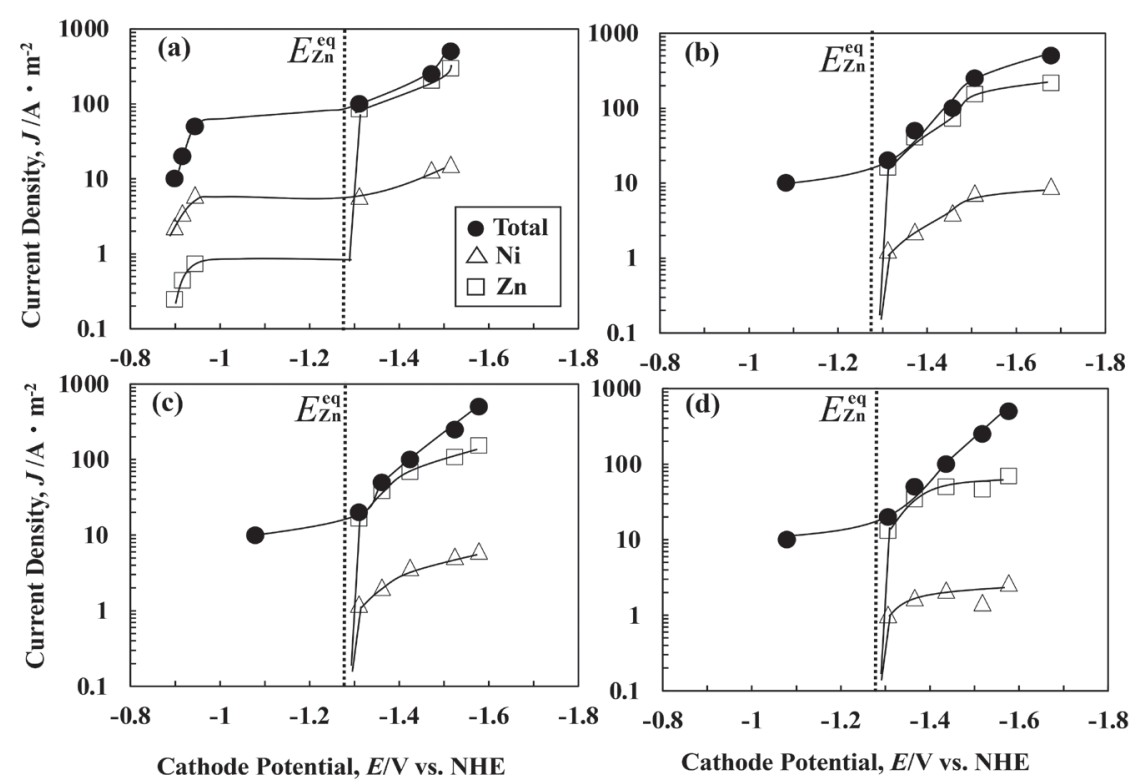

Fig. 3. Polarization curves for $\mathrm{Zn}-\mathrm{Ni}$ alloy deposition from the solutions with and without brightener. [(a) Brightener-free, (b) Brightener $1 \mathrm{ml} \cdot \mathrm{dm}^{-3}$, (c) $3 \mathrm{ml} \cdot \mathrm{dm}^{-3}$, (d) $5 \mathrm{ml} \cdot \mathrm{dm}^{-3}$ ] 
reference line, 以下 CRL と略す) である。合金の $\mathrm{Ni}$ 含有率 がこの線の上部に位置していれば, 電気化学的に貴な $\mathrm{Ni}$ 優先析出する正常型共析であり, 下部に位置していれば卑 な Znが優先析出する変則型共析となることを示す。Fig.5 （a）に示すように, 光沢剤が無い場合, Ni含有率は50〜100 $\mathrm{A} \cdot \mathrm{m}^{-2}$ の領域で大きく変化した。 $50 \mathrm{~A} \cdot \mathrm{m}^{-2}$ 以下では $\mathrm{Ni}$ 含 有率は $90 \mathrm{mass} \%$ 前後と組成参照線より上部にあり, 正常 型共析となるのに対して, $100 \mathrm{~A} \cdot \mathrm{m}^{-2}$ 以上では組成参照線 を下回り変則型共析となった。電析挙動が正常型から変則 型へ移行する電流密度は転移電流密度と称される ${ }^{25)}$ 。この 転移電流密度は, Fig.3 (a) に示す全分極曲線の電位が急激 に卑な領域に移行する電流密度打よび電流効率が大きく 変化した電流密度 (Fig.4) と対応している。一方, 光沢凬 を添加すると，その添加量に関わらず， Ni含有率は10～20 $\mathrm{A} \cdot \mathrm{m}^{-2}$ の領域で大きく変化した。 $20 \mathrm{~A} \cdot \mathrm{m}^{-2}$ 以上では組成参 照線を下回り変則型共析となった。この転移電流密度は, Fig.3 (b-d) に示す全分極曲線の電位が急激に卑な領域に移 行する電流密度および電流効率が大きく変化した電流密度 （Fig.4）と一致しており，光沢棛が無い場合より低くなっ ている。 $20 \mathrm{~A} \cdot \mathrm{m}^{-2}$ 以上で変則型共析となる領域の $\mathrm{Ni}$ 含有 率を拡大した図を Fig.5 (b) に示す。変則型共析となる領域 の $\mathrm{Ni}$ 含有率は, 光沢剤を添加すると低下しており, また総 じて光沢剤の添加量が多くなるほど低下した。

\section{$3 \cdot 3$ 電析膜の微細構造に及ぼす光沢剤の影響}

Fig.6に光沢剂の濃度を変化させた浴から $50,100,500$ $\mathrm{A} \cdot \mathrm{m}^{-2}$ で得られた電析膜の $\mathrm{SEM}$ 観察像を示す。 $50 \mathrm{~A} \cdot \mathrm{m}^{-2}$ で得られた電析膜 ( (a) - (d) ) は, 光沢剤の有無に関わら ず電析膜は粒状となっており, 電析膜の形態に及ぼす光沢 剤の影響は特に見られなかった。次に, $100 \mathrm{~A} \cdot \mathrm{m}^{-2}$ で得ら れた電析膜については, 光沢骫を含まない場合 (e) は滑ら かな粒状の形態を示したが，光沢剤を $1 \mathrm{ml} \cdot \mathrm{dm}^{-3}$ 添加する と（f）粒状が少なくなり, 平滑となった。しかし, 光沢郕 を $3 \mathrm{ml}$ 添加すると $(\mathrm{g})$, 平滑な面上に粒状の結晶が多数存 在し, 光沢郕を $5 \mathrm{ml} \cdot \mathrm{dm}^{-3}$ に増加すると (h), 粒状の結晶が 減少し平滑な箇所が増加した。一方, $500 \mathrm{~A} \cdot \mathrm{m}^{-2}$ で得られ
た電析膜については, 光沢剤を含まない浴から得られた電 析膜（i）は基板に対して直立した板状の結晶から構成され たが, 光沢片を $1 \mathrm{ml} \cdot \mathrm{dm}^{-3}$ 添加すると (j) 板状結晶が消失 し平滑となった。光沢剤の添加量を $3,5 \mathrm{ml} \cdot \mathrm{dm}^{-3}$ と増加す ると $(\mathrm{k}, 1), 100 \mathrm{~nm}$ 程度の微細な粒状結晶が見られたが全 体的により平滑となった。

Fig. $7 に 500 \mathrm{~A} \cdot \mathrm{m}^{-2}$ で得られた電析膜の X線回折図形を示 す。光沢㓱の有無に関わらずZn中に $\mathrm{Ni}$ が固溶している 相と基板の $\mathrm{Fe}$ に由来するピークのみが検出された。光沢剤 が無い浴から得られた電析膜 (a)の $\eta$ 相は, 主に $\{10 \overline{1} 1\}$, $\{0001\}$ 面に配向しているのに対して, 光沢剤を $1 \mathrm{ml} \cdot \mathrm{dm}^{-3}$ 添加すると (b) , \{10 $\overline{1} 1\},\{0001\}$ 面への配向が減少した。光 沢剤の添加量を $3,5 \mathrm{ml}$ と増加すると $(\mathrm{c}, \mathrm{d}),\{10 \overline{1} 1\},\{0001\}$ 面への配向が更に減少し, 無配向の状態に近づいた。通常 の金属電析では, 分極が大きくなると電析膜の結晶配向性 が無配向分散型となり, 皮膜の形態は素地打よび電場に無 関係な微細結晶が分散した平滑面となることが知られて いる ${ }^{26)}$ 。本研究においても, 光沢剤の添加により分極が大 きくなると電析膜は無配向分散型に近づいた。なお, 硫酸 塩浴からの $\mathrm{Zn}-\mathrm{Ni}$ の合金電析においては, $\mathrm{Ni}$ 含有率 4.8 mass\%の皮膜には $\gamma$ 相 $\left(\mathrm{NiZn}_{3}, \mathrm{Ni}_{5} \mathrm{Zn}_{21}\right.$ の金属間化合物) が 存在することが報告されているが27), 本研究のジンケート 浴からの電析では, $\gamma$ 相は検出されなかった。

Fig. 8 に $500 \mathrm{~A} \cdot \mathrm{m}^{-2}$ で得られた電析膜の結晶子径を示す。 電析膜の結晶子径は, 光沢剤の添加量が多くなる程小さく なった。一般に電析の過電圧が大きくなると, 電析膜の核形 成速度がその成長速度より相対的に速くなるため電析膜の 結晶子径は小さくなる28-31)。本研究において, 光沢剤の濃度 が高くなるほど電析膜の結晶子径が小さくなったのは, 濃 度が高くなるほど過電圧が増加したためと考えられる。

\section{$3 \cdot 4$ 電析膜の耐食性に及ぼすに及ぼす光沢剤の影響}

Fig.9に 3 mass $\% ~ N a C l$ 水溶液中における電析膜の分極曲 線を示す。光沢剤を添加して得られた電析膜は, 酸化反応 が抑制されて抢り, その結果, 腐食電位が貴な方に移行し た。腐食電位の貴側への移行の程度は, 光沢剤の添加量が
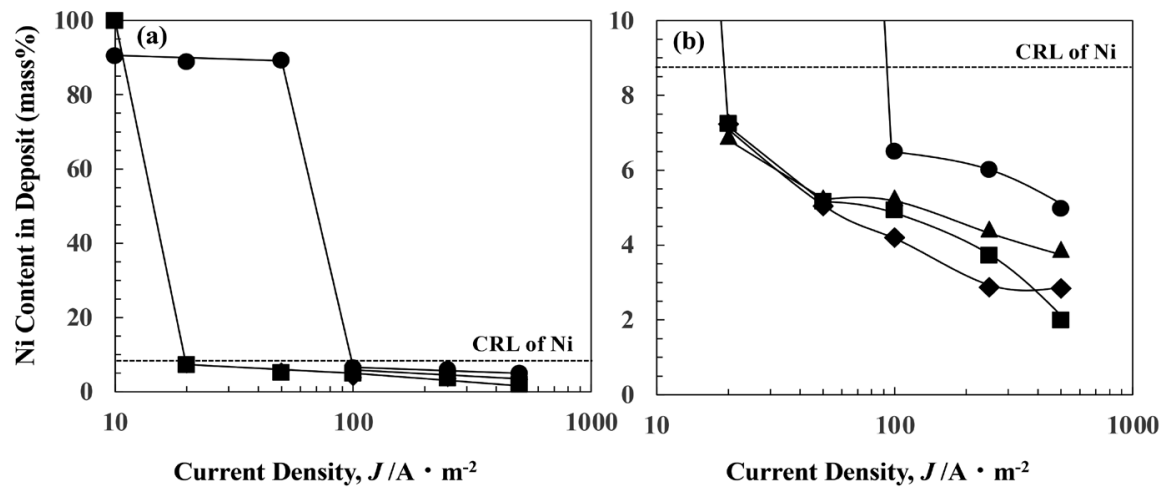

Fig. 5. Ni content in $\mathrm{Zn}-\mathrm{Ni}$ alloys deposited at various current densities from the solutions with and without brightener. (b) shows the magnified view of the area of $0-10$ mass $\%$ of Ni content. [ $\bullet$ Brightener-free, $\boldsymbol{\Delta}$ Brightener $1 \mathrm{ml} \cdot \mathrm{dm}^{-3}, \boldsymbol{\bullet} 3 \mathrm{ml} \cdot \mathrm{dm}^{-3}, \cdot 5 \mathrm{ml} \cdot \mathrm{dm}^{-3}$ ] 
多くなるほど大きくなった。一方, 腐食反応のカソード反 応である溶存酸素の還元反応は, 光沢剤の有無でほとんど 変化して打らず, その結果, 腐食電流密度に及ぼす光沢剂 添加の影響はほとんど認められなかった。光沢剂を添加す ると電析膜の溶解反応が抑制される要因については現状不 明であるが, 電析膜の微細構造の変化, 光沢剤の電析膜へ の共析等が影響を及ぼしていると推察される。

\section{4. 考察}

ジンケート浴からの Zn - Ni 合金電析挙動に及ぼすエピ クロルヒドンとイミダゾールの反応物の影響について以 下考察する。硫酸塩浴からの $\mathrm{Zn}-\mathrm{Ni}$ の合金電析において も, 本研究の場合と同様に電流効率の高い実用的な合金が 得られる電流密度領域では, 電気化学的に貴な $\mathrm{Ni} り$ 卑

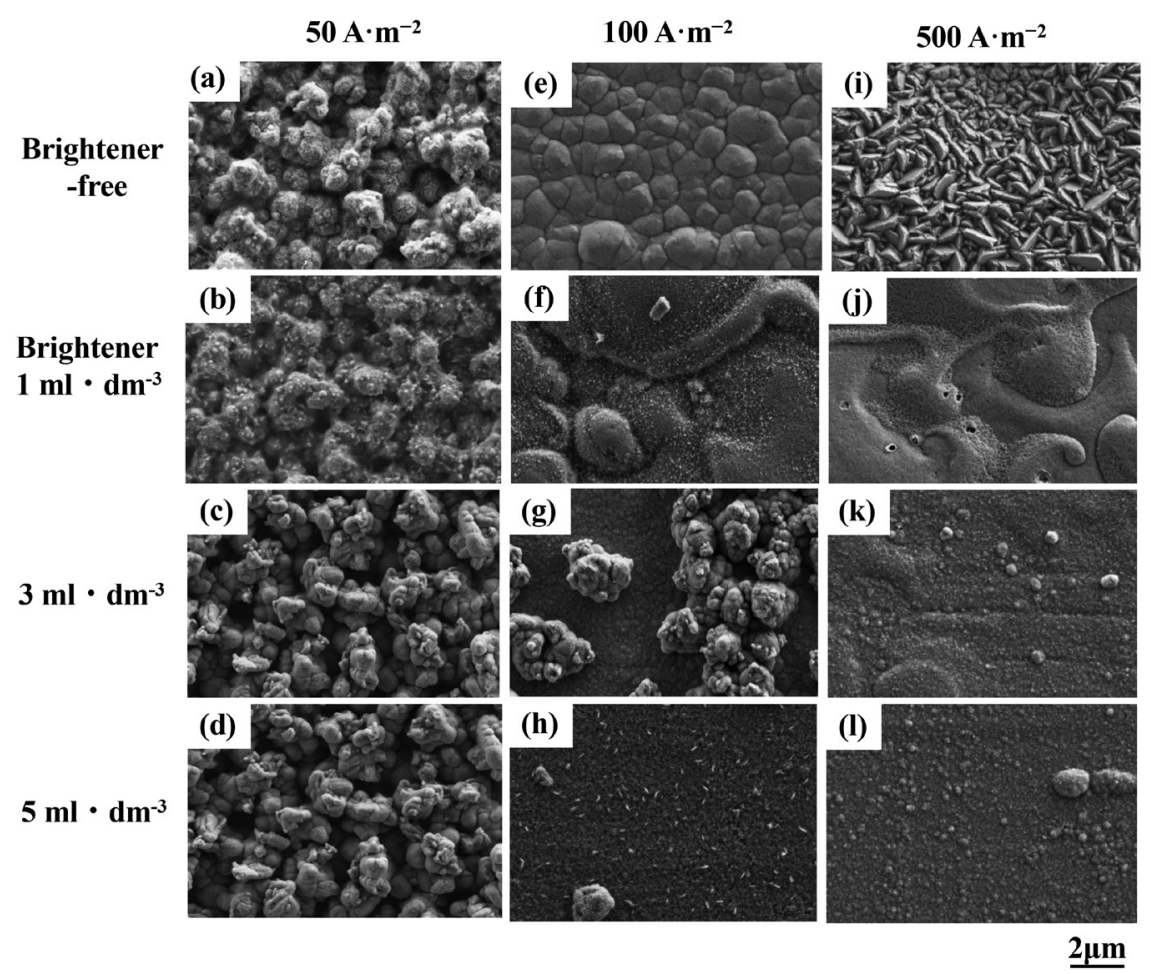

Fig. 6. SEM micrographs of the surface of $\mathrm{Zn}-\mathrm{Ni}$ alloys deposited at various current densities from the solutions containing brightener at different concentrations.
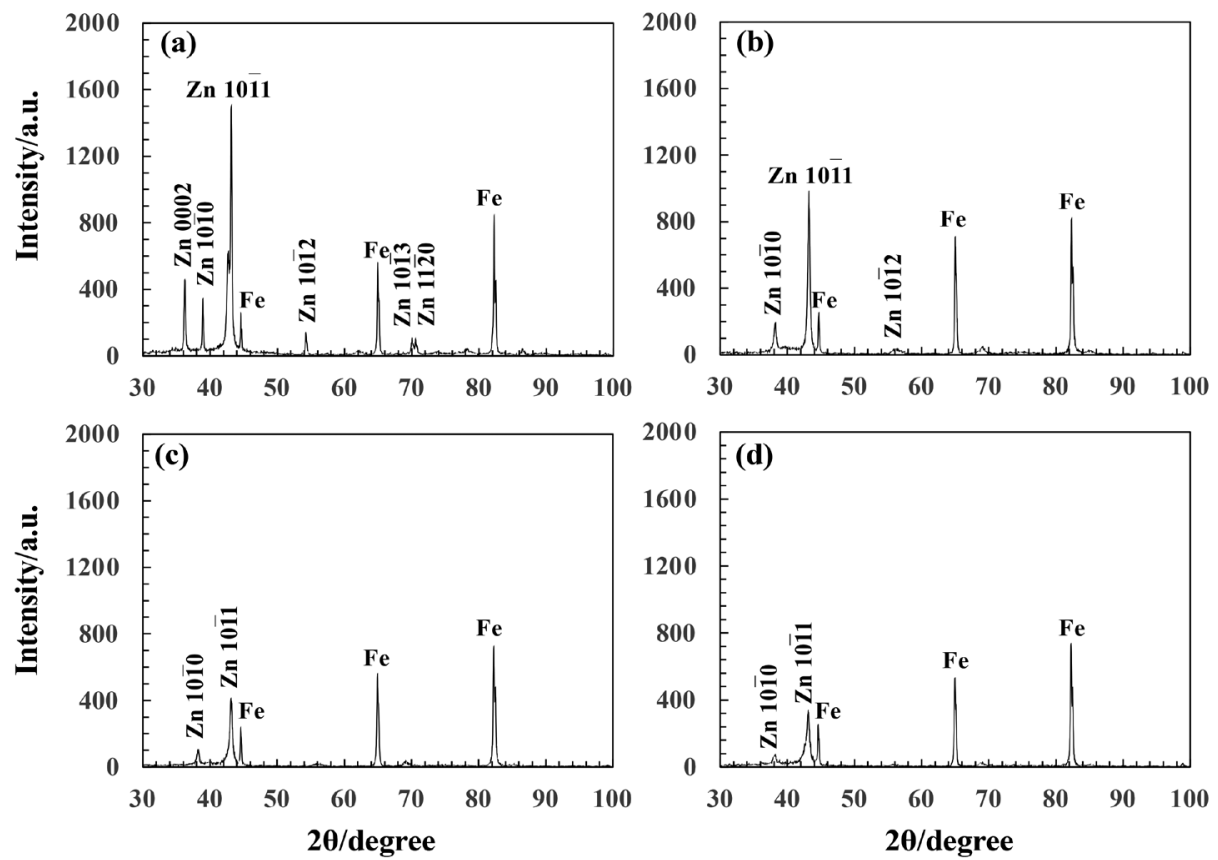

Fig. 7. X-ray diffraction patterns of $\mathrm{Zn}-\mathrm{Ni}$ alloy films deposited at $500 \mathrm{~A} \cdot \mathrm{m}^{-2}$ from the solutions with and without brightener. [(a) Brightenerfree, (b) Brightener $1 \mathrm{ml} \cdot \mathrm{dm}^{-3}$, (c) $3 \mathrm{ml} \cdot \mathrm{dm}^{-3}$, (d) $5 \mathrm{ml} \cdot \mathrm{dm}^{-3}$ ] 
な Znが優先析出する変則型共析が生じることが報告され ている ${ }^{6-10)}$ 。硫酸塩水溶液に打いて変則性が生じる原因と しては，1）水和イオンからの Ni電析が水酸基を含有した 吸着中間体 $\mathrm{NiOH}_{\mathrm{ad}}$ を経由した多段階還元機構により進行 し, $\mathrm{NiOH}_{\mathrm{ad}}$ が吸着できるサイトが制限されている，2）電解 中の水素発生に伴う陰極近傍の $\mathrm{pH}$ 上昇により生成, 吸着 した $\mathrm{Zn}(\mathrm{OH})_{2}$ が $\mathrm{NiOH}_{\mathrm{ad}}$ の吸着サイトを封鎖し $\mathrm{Ni}$ 電析の抑 制剂として作用する水酸化物抑制機構 ${ }^{6-10)}$ が提唱されてい る。アルカリジンケート浴からの Zn電析は, 界面インピー ダンス測定に基づき，下記の式 (1)〜（3）の多段階反応によ り進行することが報告されている ${ }^{32-34)}$ 。

$$
\begin{aligned}
& \mathrm{Zn}(\mathrm{OH})_{4}^{2-} \rightarrow \mathrm{Zn}(\mathrm{OH})_{3}^{-}+\mathrm{OH}^{-} \\
& \mathrm{Zn}(\mathrm{OH})_{3}^{-} \rightarrow \mathrm{Zn}(\mathrm{OH})_{2}+\mathrm{OH}^{-}
\end{aligned}
$$

$\mathrm{Zn}(\mathrm{OH})_{2}+2 \mathrm{e} \rightarrow \mathrm{Zn}+2 \mathrm{OH}^{-}$

電流密度が高い時，上記の式 $(1) \sim(3)$ の多段階反応によ り Zn 電析が生じ，陰極界面に形成される $\mathrm{Zn}(\mathrm{OH})_{2}$ が $\mathrm{Ni}$ 電 析を抑制し，変則型共析となると考えられる。

$\mathrm{Zn}$ 一鉄族金属 $(\mathrm{Ni}, \mathrm{Fe}, \mathrm{Co})$ 合金電析において, 電析挙動 が正常型から变則型へ移行する転移電流密度は, 純 $Z n$ 電

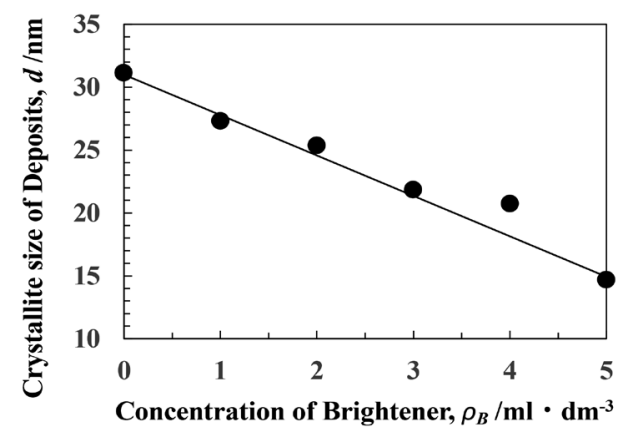

Fig. 8. Crystallite size of Zn-Ni alloy films deposited at 500 $\mathrm{A} \cdot \mathrm{m}^{-2}$ from the solutions containing various amounts of brightener.

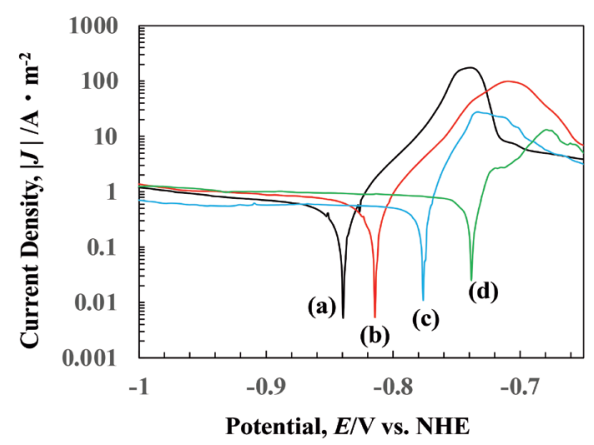

Fig. 9. Polarization curves in 3 mass $\% \mathrm{NaCl}$ solution for deposits obtained at $500 \mathrm{~A} \cdot \mathrm{m}^{-2}$ from the solutions with and without brightener. [(a) Brightener-free, (b) Brightener $1 \mathrm{ml} \cdot \mathrm{dm}^{-3}$, (c) $3 \mathrm{ml} \cdot \mathrm{dm}^{-3}$, (d) $5 \mathrm{ml} \cdot \mathrm{dm}^{-3}$ ] (online version in color).
析において Zn 電析が開始する臨界電流密度と同一の意味 を持つものであることが報告されている ${ }^{35)}$ 。本研究の $\mathrm{Zn}$ 一 Ni合金電析における転移電流密度は, 光沢剂が無い場合 は50〜 $100 \mathrm{~A} \cdot \mathrm{m}^{-2}$ であるのに対して, 光沢剂を添加した場 合は 10〜 $20 \mathrm{~A} \cdot \mathrm{m}^{-2}$ となり, 光沢剤の添加により大きく低 下した。(Fig.5 (a)) 先に述べたように転移電流密度は, 全 分極曲線の電位が Znの平衡電位より貴な領域から卑な領 域に急激に移行する電流密度と対応しており, 純Zn電析 における臨界電流密度と類似している。ここで, 純 Zn電析 打ける臨界電流密度は, 水素発生が抑制されるほど低くな ることが報告されている ${ }^{36-38)}$ 。そこで, $\mathrm{Zn}-\mathrm{Ni}$ 合金電析に おける水素発生の部分分極曲線を Fig.10に示す。比較のた め, $\mathrm{Zn}^{2+}, \mathrm{Ni}^{2+}$ イオンを含まない浴からの水素発生の部分分 極曲線を示す。 $\mathrm{Zn}-\mathrm{Ni}$ 合金電析浴からの水素発生は, $\mathrm{Zn}$ の平衡電位より貴な領域では, 光沢剂の有無に関わらず電 位が卑な方向に移行するにも関わらず一旦減少し, $\mathrm{Zn}$ の平 衡電位より卑な領域になると増加した。 $\mathrm{Zn}^{2+}, \mathrm{Ni}^{2+}$ イオンを 含まない浴からの水素発生は, 電位が卑になるほど増加し ており, Znの平衡電位近傍での低下は見られなかった。 $\mathrm{H}^{+}$ の還元反応は吸着中間体 $\mathrm{H}_{\mathrm{ad}}$ を経由した多段階還元機構に より進行し， $\mathrm{H}_{\mathrm{ad}}$ が吸着できるサイトが制限されているた め, $\mathrm{Zn}(\mathrm{OH})_{2}$ が形成されると水素発生が抑制されることが 報告されている ${ }^{35,36)}$ 。このため, $\mathrm{Zn}-\mathrm{Ni}$ 合金電析における 水素発生は, $\mathrm{Zn}$ の平衡電位近傍で電位が卑な方向に移行す るにも関わらず一旦減少したと考えられる。ここで, 水素 発生に及ぼす光沢剂の影響に着目すると, $\mathrm{Zn}$ の平衡電位よ り貴な領域では水素発生は, 光沢剤により抑制されている ことが分かる。これは， $\mathrm{H}_{\mathrm{ad}}$ が吸着できるサイトが制限され ているため $\mathrm{Zn}(\mathrm{OH})_{2}$ と同様に光沢剂が水素発生を抑制す ると考えられる。以上のことから, Zn- Ni合金電析におい て光沢剤を添加すると水素発生が抑制されるため, 転移電 流密度は低下したと考えられる。

一方, $\mathrm{Zn}-\mathrm{Ni}$ 合金電析に扎ける合金組成, 電流効率に及 ぼす光沢剂の影響については, 光沢剂は, Zn, Ni電析の両 方を抑制しており（Fig.3）, このため高電流密度域で電流効

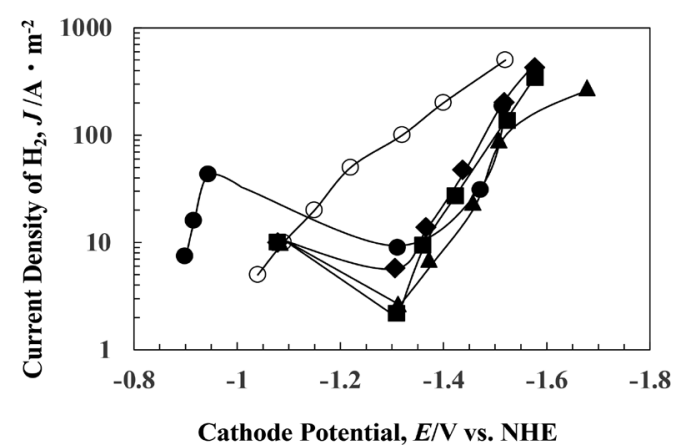

Fig. 10. Partial polarization curves for $\mathrm{H}_{2}$ evolution during $\mathrm{Zn}$ Ni alloy deposition from the solutions with and without brightener. [ $\bullet$ Brightener-free, $\boldsymbol{\Delta}$ Brightener $1 \mathrm{ml} \cdot \mathrm{dm}^{-3}$, - $3 \mathrm{ml} \cdot \mathrm{dm}^{-3}, 5 \mathrm{ml} \cdot \mathrm{dm}^{-3}, \circ\left(\mathrm{Zn}^{2+}, \mathrm{Ni}^{2+}\right.$, brightener $)$-free] 
率が低下したと考えられる。(Fig.4) 光沢剤による Zn, Ni 電析の抑制効果の相違に着目すると, 変則型共析となる領 域の Ni含有率は, 光沢剂を添加すると低下している (Fig.5 (b)）ことから Niの方がより強く抑制されることが分かる。 $\mathrm{Ni}$ 電析において中間体 $\mathrm{NiOH}_{\mathrm{ad}}$ が吸着できるサイトが制限 されていると仮定すれば, 光沢剤を添加した場合, その吸 着により限定された $\mathrm{NiOH}_{\mathrm{ad}}$ の吸着サイトが封鎖され, $\mathrm{Ni}$ 電析の方がより強く抑制されると推察される。このため, 電析膜の $\mathrm{Ni}$ 含有率は, 光沢骫を添加すると低下したと考 えられる。

$\mathrm{Zn}-\mathrm{Ni}$ 合金電析膜の外観，結晶形態に及ぼす光沢剤の 影響については, 光沢剤を含む浴から得られた電析膜の結 晶は，電流密度が高くなるほど平滑となり（Fig.6），光沢が 顕著となった (Fig.2)。即ち, 電析膜の微細構造に及ぼす光 沢郕の影響は，電流密度が高いほど大きいと言える。本研 究で用いた光沢剤は，第四級アンモニウムカチオンが結合 したポリマーであるため (Fig.1)，電流密度が高くなる程， 即ち陰極電位が卑になる程，陰極への静電的な吸着力が大 きくなるためその効果が大きくなると考えられる。

\section{5. 結言}

ジンケート浴からの Zn - Ni 合金電析挙動に及ぼす光沢 剂の影響を $\mathrm{Zn}, \mathrm{Ni}$ 析出および水素発生の部分分極曲線に より調查した。光沢剤としては, エピクロルヒドリンとイ ミダゾールの反応物を用いた。電析挙動が正常型から変則 型へ移行する転移電流密度は，光沢剤が無い場合は50 $100 \mathrm{~A} \cdot \mathrm{m}^{-2}$ であるのに対して，光沢剤を添加した場合は 10〜20 A $\cdot \mathrm{m}^{-2}$ となり, 光沢剤の添加により大きく低下し た。転移電流密度は, 全分極曲線の電位が $\mathrm{Zn}$ の平衡電位よ り貴な領域から卑な領域に急激に移行する電流密度と一致 した。光沢剂を添加すると水素発生が抑制されるため転移 電流密度は低下したと考えられる。光沢剤を添加する Zn, $\mathrm{Ni}$ 電析共に抑制されるため高電流密度域で合金電析の電 流効率が低下した。また, 電析膜の $\mathrm{Ni}$ 含有率は, 光沢剤を 添加すると低下していることから $\mathrm{Ni}$ 電析の方がより強く 抑制されることが分かった。光沢郕を含む浴から得られた 電析膜の結晶は, 電流密度が高くなるほど平滑となり, 光 沢が顕著となった。光沢剤を添加すると電析膜の酸化反応 が抑制されており，その結果，腐食電位が貴に移行した。

\section{文献}

1 ) L.Fellonu, R.Frratesi, E.Quadrini and G.Roventi: J. Appl. Electrochem., 17(1987), 574

2 ) M.F.Mathias and T.W.Chapman: J. Electrochem. Soc., 134(1987), 1408.

3 ) S.Swathirajan: J. Electronal. Chem., 221(1987), 211.

4 ) T.Fujigaya: Electroplating, Chemical Plating \& Engineering Guide, Nippon Tokin Zairyo Kyodo Kumiai, Tokyo, (2004), 143 (in Japanese).
5 ) M.Kawasaki and H.Enomoto: Mekki Kyohon (Textbook for plating), Nikkan Kogyo Shimbun, Tokyo, (1988),108 (in Japanese).

6 ) A.Brenner: Electrodeposition of Alloys, Vols.1,2, Academic Press, New York, (1963), 221.

7 ) H.Fukushima, T.Akiyama, J.Lee, M.Yamaguchi and K.Higashi: $J$. Met. Finish. Soc. Jpn., 33(1982), 574 (in Japanese).

8 ) H.Fukushima, T.Akiyama, M.Yano, T.Ishikawa and R.Kammel: ISIJ Int., 33(1993), 1009.

9 ) H.Nakano, S.Kobayashi, T.Akiyama, T.Tsuru and H.Fukushima: Tetsu-to-Hagané, 89(2003), 64 (in Japanese).

10) H.Nakano, M.Matsuno, S.Oue, M.Yano, S.Kobayashi and H.Fukushima: J. Jpn. Inst. Met., 69(2005), 548 (in Japanese).

11) M.G.Hosseini, H.Ashassi-Sorkhabi and H.A.Y.Ghiasvand: Surf. Coat. Technol., 202(2008), 2897.

12) L.S.Tsybulskaya, T.V.Gaevskaya, O.G.Purovskaya and T.V.Byk: Surf. Coat. Technol., 203(2008), 234.

13) G.Y.Li, J.S.Lian and Z.H.Jiang: Surf. Coat. Technol., 191(2005), 59.

14) N.R.Short, S.Zhou and J.K.Dennis: Surf. Coat. Technol., 79(1996), 218.

15) C.Muller, M.Sarret and M.Benballa: J. Electroanal. Chem., $\mathbf{5 1 9}(2002), 85$.

16) H.Y.Lee and S.G.Kim: Surf. Coat. Technol., 135(2000), 69

17) H.Nakano, S.Arakawa, Y.Takada, S.Oue and S.Kobayashi: J. Jpn. Inst. Met., 76(2012), 443 (in Japanese).

18) H.Nakano, S.Arakawa, S.Oue and S.Kobayashi: Tetsu-to-Hagané, 99(2013), 425 (in Japanese).

19) H.Nakano, S.Arakawa, Y.Takada, S.Oue and S.Kobayashi: Mater. Trans., 53(2012), 1946.

20) H.Nakano, S.Arakawa, S.Oue and S.Kobayashi: ISIJ Int., 53(2013), 1864.

21) H.Nezu, S.Fujii, N.Kaneko and N.Ofuchi: J. Met. Finish. Soc. Jpn., 32(1982), 17 (in Japanese).

22) S.Konishi, S.Eguchi, N.Ozeki and M.Uesugi: J. Met. Finish. Soc. Jpn., 20(1969), 263 (in Japanese).

23) T.Watanabe: J. Surf. Finish. Soc. Jpn., 40(1989), 280 (in Japanese).

24) D.D.Perrin: Stability Constants of Metal-ion Complexes, Part B, Organic Compounds, Pergamon Press, Oxford, (1979), 466.

25) T.Akiyama, H.Fukushima and K.Higashi: Tetsu-to-Hagané, 72(1986), 918 (in Japanese).

26) R.Winand: J. Appl. Electrochem., 21(1991), 377.

27) A.Shibuya, T.Kurimoto, K.Korekawa and K.Noji: Tetsu-to-Hagané, 66(1980), 771 (in Japanese).

28) S.Haruyama: Hakumaku Zairyo no Kiso to Ohyo (Foundation and application of thin film materials), The Japan Institute of Metals, Sendai, (1987), 37 (in Japanese).

29) H.Nakano, S.Oue, T.Miki, S.Kobayashi and H.Fukushima: ISIJ Int., 46(2006), 106

30) H.Nakano, S.Oue, Y.Hamaguchi, S.Kobayashi, H.Fukushima: ISIJ Int., 49(2009), 1769.

31) H.Nakano: Trans. Nonferr. Met. Soc. China, 19(2009), 835.

32) T.Yamashita and S.Toshima: Nippon Kagaku Kaishi, 1980(1980), 1824 (in Japanese).

33) K.Aotani: Gokin Mekki VI(Alloy plating VI), Nippon Plating Kyokai, Tokyo, (2005), 133 (in Japanese).

34) T.Yoshida: New Engineering Review of Coating, Sangyo Gizyutsu Service Center, Tokyo, (1987), 318 (in Japanese).

35) H.Fukushima and H.Nakano: J. Surf. Sci. Soc. Jpn., 22(2001), 107 (in Japanese).

36) H.Nakano, T.Ohgai, H.Fukushima,T.Akiyama and R.Kammel: Metall, 55(2001), 676 .

37) H.Fukushima, T.Akiyama and T.Ohgai: J. MMIJ, 110(1994), 967 (in Japanese).

38) H.Fukushima, T.Akiyama and K.Kiyotani: J. MMIJ, 109(1993), 861 (in Japanese). 